\title{
METODOLOGIA APLICADA À PROMOÇÃO DE SAÚDE BUCAL DURANTE O PROJETO RONDON: OPERAÇÃO VALE DO RIBEIRA 2006
}

Luis Ricardo Prevedello PEREIRA; Felipe Ambrósio TEODORO; Érika Ferreira de PAULA; Vanessa CHAVES

O Projeto Rondon foi retomado em julho de 2006 com a Operação Vale do Ribeira. O presente trabalho externa as ações de promoção de saúde bucal realizadas na área rural do município de Campina Grande do Sul. Foi realizado um diagnóstico das condições de saúde bucal da população durante as visitas domiciliares e idas as escolas. Verificou-se que as condições de saúde bucal estavam muito aquém do previsto pela OMS. Frente a essa situação, a equipe buscou conceituar e educar a população com relação aos riscos de uma higiene bucal deficiente. Durante os 15 dias de trabalho foram desenvolvidas atividades educativas utilizando-se teatros infantis, palestras educativas, pintura, instrução de higiene bucal e oficinas de capacitação para os agentes comunitários. Com esse trabalho foram beneficiadas 100 pessoas com palestras educativas, incluindo crianças, adultos e idosos, 80 famílias foram visitadas, 80 pessoas tiveram atendimento odontológico e 56 agentes comunitários participaram da capacitação em saúde bucal os quais serão os multiplicadores desses trabalhos. Portanto, medidas alternativas de educação são de suma importância em regiões onde há um déficit de atenção aos princípios básicos de saúde e que podem perpetuar como soluções de curto, médio e longo prazo. 